Check for updates

Cite this: RSC Adv., 2018, 8, 31267

\title{
Nutrient value of fish manure waste on lactic acid fermentation by Lactobacillus pentosus
}

\author{
Suan Shi, ${ }^{a}$ Jing Li, ${ }^{\text {b }}$ Wenjian Guan ${ }^{c}$ and David Blersch (D) *a
}

The aim of this work was to study the feasibility of using fish manure waste as a nutrient source for lactic acid fermentation. Fish waste contains nitrogen and minerals that could support the growth of lactic acid bacteria (LAB), making it a good candidate as the nutrient source for lactic acid fermentation. Two different fish manure wastes, from Nile tilapia and channel catfish aquaculture, were investigated for their performance on different sugar substrates. Both fish waste types showed low efficiency in the direct fermentation of glucose, but satisfactory efficiencies in simultaneous saccharification and fermentation (SSF) of cellulosic materials, such as pure cellulose and paper sludge. The highest lactic acid yield obtained was $87 \%$ and $91 \%$, with a corresponding volumetric productivity of 1.006 and $0.580 \mathrm{~g} \mathrm{~L}^{-1} \mathrm{~h}^{-1}$, and corresponding lactic acid concentration of 96 and $56 \mathrm{~g} \mathrm{~L}^{-1}$ for cellulose and paper sludge, respectively. Fish waste concentrations did not show much impact on lactic acid production for the SSF process, where increasing fish waste from 10 to $30 \mathrm{~g} \mathrm{~L}^{-1}$ resulted in less than a $10 \%$ yield increase. In the present study, fish manure waste was shown to be an effective and economic nutrient source for lactic acid production by SSF.

rsc.li/rsc-advances

\section{Introduction}

Lactic acid is an important organic acid with wide applications in cosmetics, pharmaceuticals, textiles, and food industries. Its most promising application is use as a starting material for the production of biodegradable poly-lactic acid (PLA), ${ }^{1}$ an environmentally-friendly plastic with a carbon neutral life cycle. ${ }^{2}$ The global market for lactic acid has been growing steadily and rapidly since 2008, with the market demand reaching $800000 \mathrm{MT}$ in 2013 and expected to exceed 1000000 MT by $2020 .^{3}$ Currently, over $90 \%$ of lactic acid is produced globally by microbial fermentation processes. ${ }^{4}$

To reduce the feedstock cost, considerable research has focused on the fermentation of carbohydrates derived from renewable lignocellulosic biomass and/or waste materials for lactic acid production..$^{5-8}$ However, less attention has been paid to the nutrient supplement in lactic acid production, which accounts for almost $30 \%$ of the overall process cost. ${ }^{9}$ The microbial fermentation processes in lactic acid production suffer from the need for an expensive nutrient supply to lactic acid bacteria (LAB). The general habitat of the LAB is a nutritious environment, so they have developed a typical metabolism that uses proteolysis to generate free amino acids for growth. ${ }^{\mathbf{1 0}}$

${ }^{a}$ Department of Biosystems Engineering, Auburn University, AL 36849, USA. E-mail: dmb0040@auburn.edu

${ }^{b}$ The Alabama Center for Paper and Bioresource Engineering, Auburn University, $A L$ 36849, USA

'John A Paulson School of Engineering and Applied Sciences, Harvard University, MA 02138 , USA
As a result, these bacteria have a very limited capability for the biosynthesis of amino acids and need external nutrient sources to maintain growth. Specific minerals, vitamins, peptides and some unknown nutrients are needed to ensure their optimal growth. ${ }^{11,12}$ Yeast extract (YE) is considered to be the best nutrient source for lactic acid fermentation, ${ }^{\mathbf{1 3}}$ and is typically used as laboratory standards. Because of its high cost, however, it is economically unfavorable for larger scales, and low-cost alternative sources are desirable. Some studies have been carried out to develop low-cost nutrient sources from waste materials, such as fish processing waste, ${ }^{14}$ rice bran, ${ }^{15}$ vinification lees, ${ }^{16}$ soy protein hydrolysate,${ }^{17}$ and unpolished rice from aging paddy. ${ }^{18}$ The utilization of these sources could reduce the nutrient cost to some extent, but most require a complicated pretreatment step, such as enzymatic or chemical hydrolysis, adding additional cost to the process. Additionally, previous studies on these nutrient sources were carried out on substrate from either pure glucose or from lignocellulosic material using a separate hydrolysis and fermentation (SHF) process. The nutrient effect on lactic acid production from the equally viable simultaneous saccharification and fermentation (SSF) process has rarely been studied.

The reuse of waste effluent from aquaculture for economic bioproducts has been of increasing interest recently. Because of their market popularity and productivity in aquaculture, both tilapia and catfish production are potentially good candidates for conversion and reuse of wastes. Globally, tilapia is the second most important group of farmed fish after carp. ${ }^{19}$ In 2015, around 19 million pounds of tilapia was produced 
domestically in U.S. ${ }^{20}$ and tilapia farming produces $38.4 \mathrm{~kg}$ of nitrogen wastes per ton of harvested fish. ${ }^{21}$ Likewise, catfish farming is one of the largest segments of U.S. aquaculture industry. Over 215 million pounds of food-size catfish was produced in 2017, with an economic market sector worth US\$355M. ${ }^{22}$ An estimated $3 \times 10^{9} \mathrm{~m}^{3}$ of wastewater and $14 \times$ $10^{3}$ MT of solid waste are generated by catfish farming in the U.S. annually. ${ }^{23}$ Solid fish wastes (manure) are commonly disposed by applying them to farmland as a fertilizer supplement, retaining them in ponds, or collecting and dewatering for composting. ${ }^{23}$ The cost of waste management for aquaculture is typically in the range of $\$ 0.05$ to $\$ 0.065$ per pound of fish produced, ${ }^{24}$ and so can contribute to overall costs of production and reduce farmer net income. In addition, improper management of fish manure wastes could have a negative environmental impact, such as eutrophication effects on natural aquatic ecosystems. Compared to lignocellulosic biomass, solid waste from fish farming has some unique characteristics suitable for lactic acid fermentation, such as a high amounts of nutritional proteins with a balanced pattern of amino acids essential for the fermentation microorganisms. ${ }^{25}$

In our previous study, it was found that catfish manure waste could be directly used as both carbon and nitrogen sources for lactic acid production. ${ }^{26}$ Since the nutrient source is the largest contributor to the total cost of lactic acid production, ${ }^{15}$ the use of fish waste as nutrient source possesses priority over that as carbon source. As such, this study is an extension of our previous study. The objective of this study is to investigate the feasibility of using either catfish waste (CW) or tilapia waste (TW) from aquaculture operations as a nutrient source for lactic acid fermentation. The performance of these two fish wastes was investigated on three different carbohydrate substrates: glucose, cellulose and paper sludge. Yeast extract was used as nutrient standard to compare with the results of the two fish wastes. The simultaneous saccharification and fermentation (SSF) process was applied in fermenting the cellulosic feedstocks, as this could eliminate the sugar end-production inhibition and thus increase the final lactic acid concentration.

\section{Materials and methods}

\subsection{Fish waste characterization}

Catfish and tilapia manure waste were collected from aquaculture operations at the North Auburn Fisheries Unit at Auburn University. Catfish solid waste was collected from the outfall of in-pond raceway systems using a settling and collection pumping system, from channel catfish (Ictalurus punctatus) being fed standard soy-based protein feed. Tilapia solid waste was collected from settling tanks receiving waste from Nile tilapia (Oreochromis niloticus) tanks operated as biofloc technology at Auburn. ${ }^{27}$ All collected waste was stored at $4{ }^{\circ} \mathrm{C}$ immediately. In general, the solid waste samples contained fish manure and a negligible amount of uneaten soybean feed. Elemental analysis was done at the Alabama Soil Testing Laboratory (Auburn, Alabama), and the results are shown in Table $1 .^{28}$ The carbohydrates composition of two manure waste
Table 1 Elemental analysis of fish wastes for major elemental components, in per weight basis

\begin{tabular}{lll}
\hline & \multicolumn{2}{l}{ Amount } \\
\cline { 2 - 3 } Element & Catfish waste & Tilapia waste \\
\hline $\mathrm{C}$ & $39.55 \%$ & $4.53 \%$ \\
$\mathrm{~N}$ & $3.12 \%$ & $0.46 \%$ \\
$\mathrm{P}$ & $0.94 \%$ & $0.40 \%$ \\
$\mathrm{~K}$ & $0.15 \%$ & $0.03 \%$ \\
$\mathrm{~S}$ & $0.34 \%$ & $0.00 \%$ \\
$\mathrm{Ca}$ & $1.86 \%$ & $1.03 \%$ \\
$\mathrm{Mg}$ & $0.08 \%$ & $0.08 \%$ \\
$\mathrm{Fe}$ & $25206 \mathrm{ppm}$ & $574 \mathrm{ppm}$ \\
$\mathrm{Mn}$ & $3349 \mathrm{ppm}$ & $87 \mathrm{ppm}$ \\
$\mathrm{Na}$ & $614 \mathrm{ppm}$ & $131 \mathrm{ppm}$ \\
& &
\end{tabular}

samples were analyzed according to the National Renewable Energy Laboratory (NREL) standard procedure, ${ }^{29}$ and the results are shown in Table 2.

\subsection{Carbohydrate substrates}

Three different materials were used for carbohydrate substrates. Dextrose, anhydrous of ACS grade (Acros Organics) was used for direct lactic acid fermentation. Microcrystalline cellulose (Alfa Aesar) was used in SSF process. Paper sludge was collected from the wastewater clarifier unit of a Kraft paper mill, Boise Paper Company (Jackson, AL), and stored at $4{ }^{\circ} \mathrm{C}$ before further use. The paper sludge was analyzed according to the NREL standard procedures $^{29}$ and found to contain $47.6 \%$ glucan, $7.5 \%$ xylan, $6.6 \%$ lignin, $34.5 \%$ ash and $44.2 \%$ moisture.

\subsection{Enzyme and microorganism}

Cellulase enzyme (Novozymes Cellic CTec2, Batch VCNI0001, 119 FPU per $\mathrm{mL}$ ) was used to hydrolyze cellulose and paper sludge during SSF. Lactobacillus pentosus (ATCC-8041) was used as the microorganism, as it can use both hexoses and pentoses in its metabolism. Lactobacilli MRS Broth (Acumedia) was used as the growth medium for preparation of inoculum. The strain was incubated in a stationary state at $37{ }^{\circ} \mathrm{C}$ for 24 hours in the MRS media.

\subsection{Nutrient effect test of fish wastes}

The nutrient performance of catfish and tilapia waste was tested on three difference carbohydrate substrates solutions: glucose solution of $100 \mathrm{~g} \mathrm{~L}^{-1}$, cellulose with solid loading of $10 \mathrm{wt} \%$, and paper sludge with solid loading of $10 \mathrm{wt} \%$. Meanwhile, DI water was used as a blank substrate to quantify the lactic acid produced by the fish wastes rather than from the substrates. The lactic acid fermentation was carried out in $125 \mathrm{~mL}$ serum bottles with a working volume of $50 \mathrm{~mL}$. Calcium carbonate was added ( $0.5 \mathrm{~g} \mathrm{~g}^{-1}$ sugar) as a $\mathrm{pH}$ buffer during fermentation to keep values near optimal. Enzyme loading of 20 FPU per $g$ glucan was applied for cellulose and paper sludge. Different levels of YE (Acros Organics) and fish wastes in the range of 5$30 \mathrm{~g} \mathrm{~L}^{-1}$ were applied to investigate their effect on lactic acid 
Table 2 Carbohydrates analysis of fish wastes, in per weight basis

\begin{tabular}{lll}
\hline & Percentage $\%$ & \\
\cline { 2 - 3 } Component & Catfish waste & Tilapia waste \\
\hline Glucan & 9.0 & 6.7 \\
Xylan & 7.1 & 3.5 \\
Galactan & 2.9 & 1.8 \\
Arabinan & 5.8 & 3.5 \\
Mannan & 0.6 & 1.2
\end{tabular}

production. For each serum bottle loaded with slurry, the contents were flushed with nitrogen gas for $5 \mathrm{~min}$ to remove oxygen, and crimp-sealed with a rubber stopper to maintain anaerobic conditions during the fermentation. The slurries were then steam sterilized at $121{ }^{\circ} \mathrm{C}$ for $15 \mathrm{~min}$. The microorganism inoculum and enzyme were then injected after the bottles cooled to room temperature after sterilization. For all trials, the microorganism inoculum volume was $3.0 \mathrm{~mL}$. To maintain anaerobic conditions, the bottles were kept sealed throughout the fermentation, and samples were collected by syringe at a $6 \mathrm{~h}$ interval for the first 48 hours of fermentation, and then at a $12 \mathrm{~h}$ interval for fermentation up to 96 hours. Fermentation was performed at $37^{\circ} \mathrm{C}$ and $150 \mathrm{rpm}$ in a rotary- action incubator-shaker and allowed to continue for $96 \mathrm{~h}$ or until no appreciable additional lactic acid production was observed. Experimental trials were carried out in duplicate. To better compare the performance of fish wastes and YE in the lactic acid fermentation, the equivalent nitrogen input was calculated by eqn (1).

$$
\begin{aligned}
\text { Nitrogen input }= & (\text { nitrogen percentage }) \times \\
& (\text { nutrients concentration }) \times(\text { volume })
\end{aligned}
$$

\subsection{Analytical methods}

Sugars were determined by HPLC equipped with refractive index detector (Shodex, Japan) using a BioRad-HPX-87P column. Lactic acid concentrations of samples were determined by HPLC using a BioRad-HPX-87H column. Where applicable, statistical analysis was performed including mean value and standard error. To show the lactic acid production rate, volumetric productivity $(P)$ was calculated as the concentration of lactic acid produced per liter divided by the fermentation time (h) and expressed in units of $\mathrm{g} \mathrm{L}^{-1} \mathrm{~h}^{-1}$. Lactic acid yield was defined as lactic acid produced divided by the total amount of available sugars.

Table 3 Effect of nutrients on lactic acid production from different carbohydrate substrates. YE: yeast extract; CW: Catfish waste; TW: Tilapia

\begin{tabular}{|c|c|c|c|c|c|c|}
\hline \multirow[t]{8}{*}{ Glucose $\left(100 \mathrm{~g} \mathrm{~L}^{-1}\right)$} & \multirow[t]{3}{*}{ YE } & 5 & 38 & 41 & 0.364 & 22.25 \\
\hline & & 15 & 91 & 99 & 2.168 & 66.75 \\
\hline & & 20 & 91 & 99 & 2.168 & 89.00 \\
\hline & \multirow[t]{2}{*}{$\mathrm{CW}$} & 10 & 18 & 20 & 0.192 & 15.50 \\
\hline & & 30 & 44 & 48 & 0.460 & 46.50 \\
\hline & \multirow[t]{3}{*}{ TW } & 10 & 76 & 83 & 0.795 & 2.50 \\
\hline & & 20 & 89 & 97 & 0.930 & 5.00 \\
\hline & & 30 & 91 & 99 & 0.949 & 7.50 \\
\hline \multirow[t]{6}{*}{ Cellulose (10 wt\%) } & \multirow[t]{2}{*}{ YE } & 5 & 93 & 84 & 0.971 & 22.25 \\
\hline & & 10 & 98 & 88 & 1.015 & 44.50 \\
\hline & $\mathrm{CW}$ & 30 & 93 & 84 & 0.971 & 46.50 \\
\hline & \multirow[t]{3}{*}{ TW } & 10 & 89 & 80 & 0.925 & 2.50 \\
\hline & & 20 & 89 & 80 & 0.925 & 5.00 \\
\hline & & 30 & 96 & 87 & 1.006 & 7.50 \\
\hline \multirow[t]{8}{*}{ Paper sludge (10 wt\%) } & \multirow[t]{3}{*}{ YE } & 5 & 57 & 94 & 0.599 & 22.25 \\
\hline & & 10 & 58 & 95 & 0.605 & 44.50 \\
\hline & & 15 & 59 & 96 & 0.612 & 66.75 \\
\hline & \multirow[t]{4}{*}{ CW } & 10 & 52 & 85 & 0.542 & 15.50 \\
\hline & & 15 & 53 & 86 & 0.548 & 23.25 \\
\hline & & 20 & 55 & 90 & 0.573 & 31.00 \\
\hline & & 30 & 54 & 88 & 0.561 & 46.50 \\
\hline & TW & 10 & 50 & 82 & 0.522 & 2.50 \\
\hline
\end{tabular}
waste. Fermentation strategy was direct fermentation for glucose, and SSF for cellulose and paper sludge 

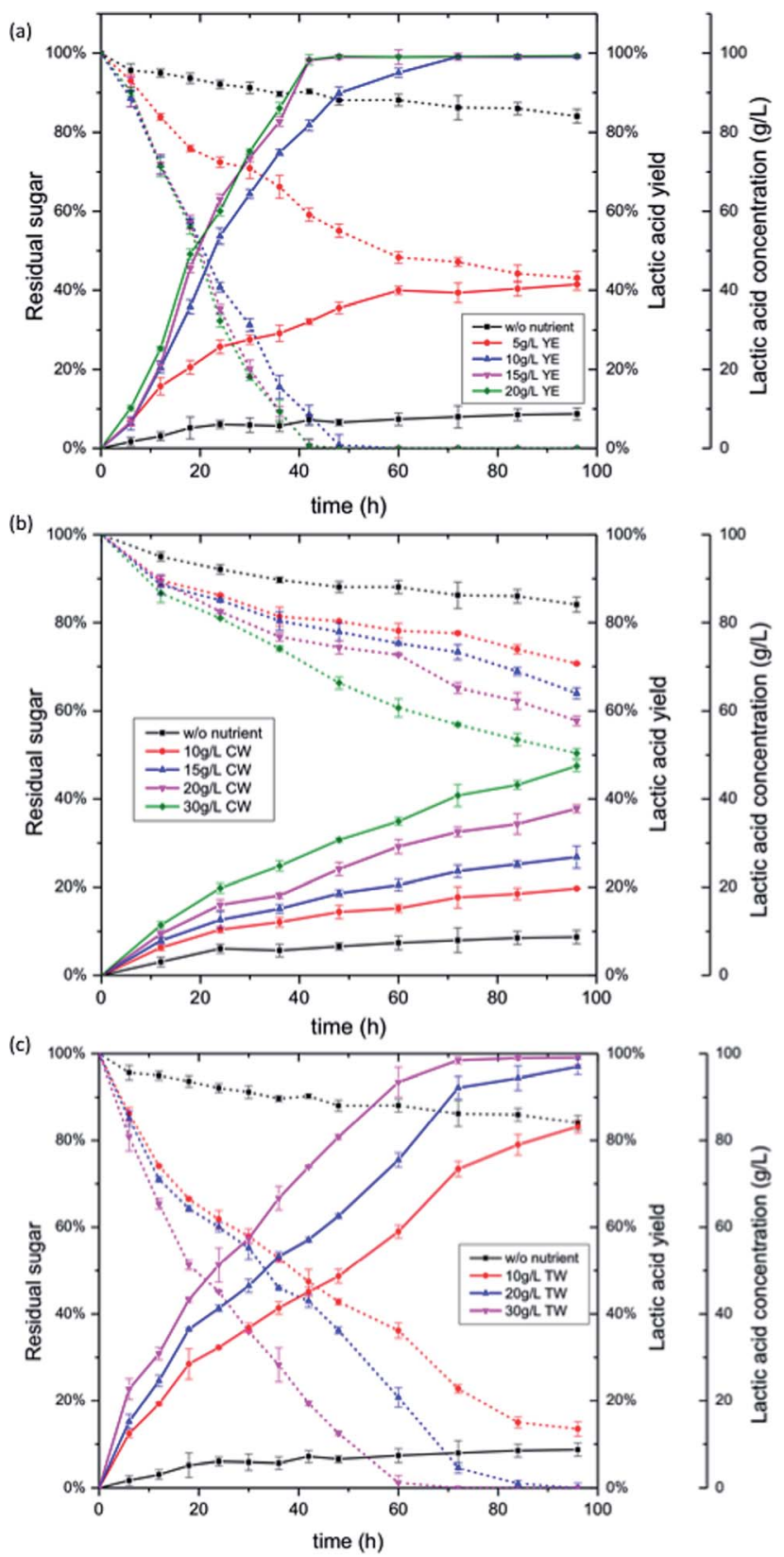

Fig. 1 Effect of different nutrients on lactic acid production from glucose $\left(100 \mathrm{~g} \mathrm{~L}^{-1}\right.$ glucose solution, direct fermentation at $37^{\circ} \mathrm{C}$ and $150 \mathrm{rpm})$. Solid line: lactic acid yield/concentration; dashed line: residual sugar. (a) YE as nutrient source; (b) CW as nutrient source; (c) TW as nutrient source.

\section{Results and discussion}

\subsection{Effect of different nutrients on lactic acid production from glucose}

Yeast extract was shown to be an excellent nutrient for most $\mathrm{LAB}$, according to previous reports, and therefore has been used as a standard nutrient source in laboratory lactic acid fermentation..$^{\mathbf{8}, 13,15,30}$ The YE used in this study was analyzed to contain $8.9 \%$ nitrogen. The nutrient effect of YE on lactic acid production by Lactobacillus pentosus (ATCC-8041) was investigated as (a)

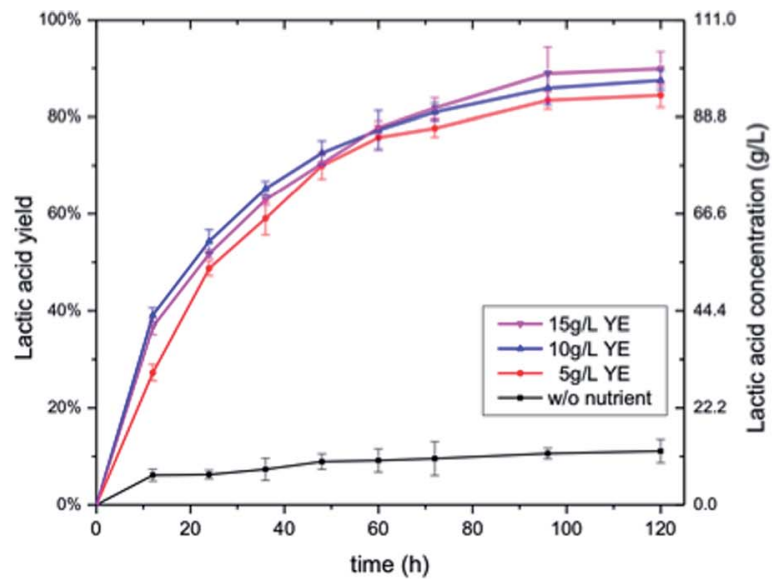

(b)

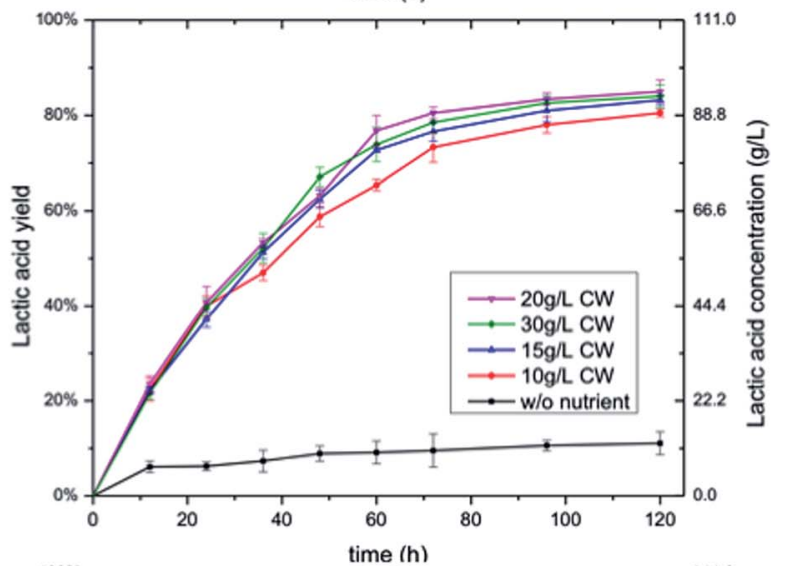

(c)

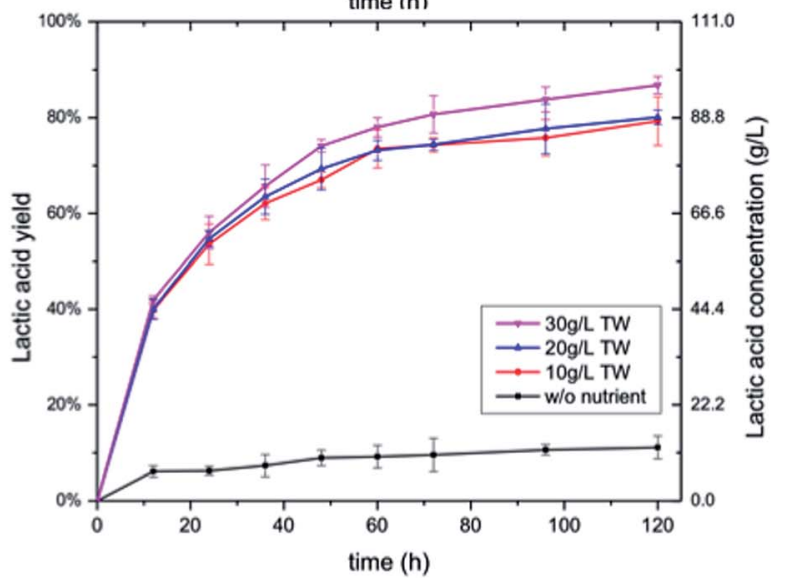

Fig. 2 Effect of different nutrients on lactic acid production from cellulose (10 wt\% cellulose loading, $20 \mathrm{FPU}$ per g glucan enzyme loading, SSF at $37^{\circ} \mathrm{C}$ and $150 \mathrm{rpm}$ ). (a) YE as nutrient source; (b) CW as nutrient source; (c) TW as nutrient source.

control and compared to the results of fish wastes. Table 3 is the summary of lactic acid yield and productivity for different nutrients and substrates tested in this study. The lactic acid produced by this LAB is racemic lactic acid (mixture of the $\mathrm{D}^{-}$ and L-lactic acid in equal amounts).

When glucose was used as the carbohydrate source, four different loadings of YE were applied: 5, 10, 15 and $20 \mathrm{~g} \mathrm{~L}^{-1}$. The results showed that YE concentration had a significant effect on lactic acid productivity (Fig. 1a). The fermentation with no nutrient was highly insufficient; the majority of glucose remained 
(a)

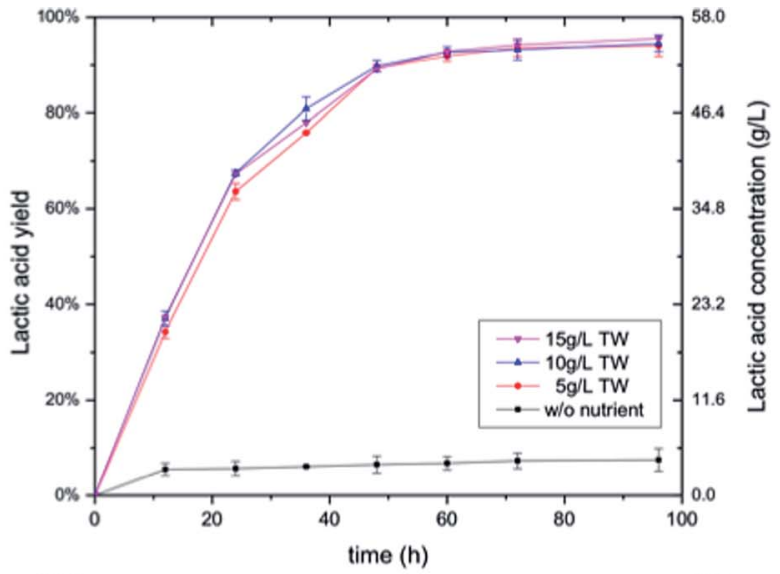

(b)

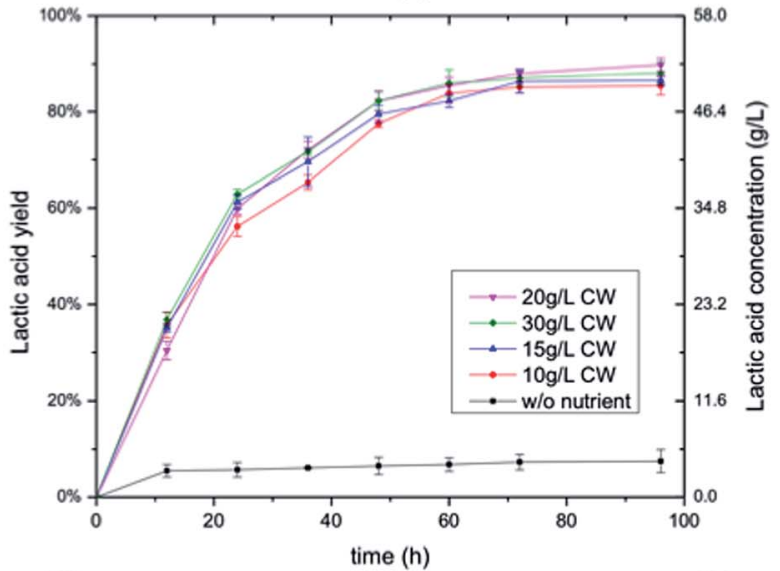

(c)

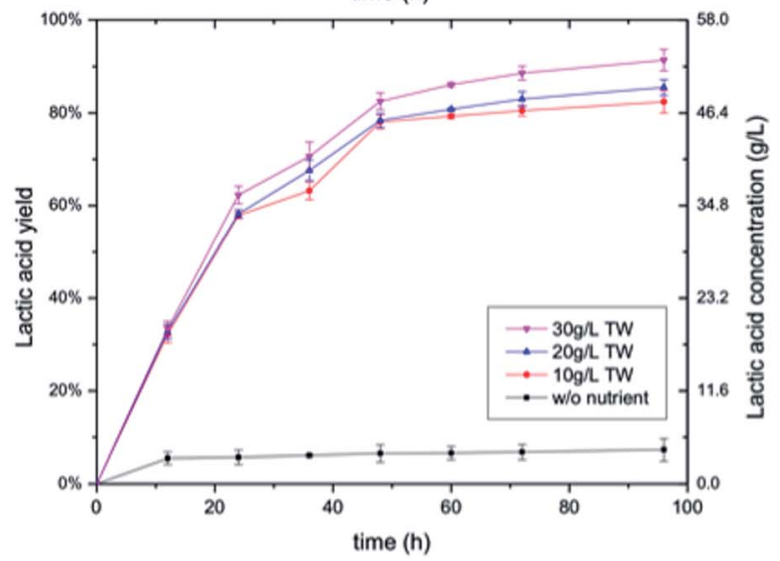

Fig. 3 Effect of different nutrients on lactic acid production from paper sludge (10 wt\% paper sludge loading, 20 FPU per g glucan enzyme loading, SSF at $37^{\circ} \mathrm{C}$ and $150 \mathrm{rpm}$ ). (a) YE as nutrient source; (b) CW as nutrient source; (c) TW as nutrient source.

after $96 \mathrm{~h}$, and only $8.1 \mathrm{~g} \mathrm{~L}^{-1}$ lactic acid was produced with a volumetric productivity of $0.084 \mathrm{~g} \mathrm{~L}^{-1} \mathrm{~h}^{-1}$. With a YE loading of $5 \mathrm{~g} \mathrm{~L}^{-1}$, the final lactic acid concentration increased to $38.3 \mathrm{~g} \mathrm{~L}^{-1}$ with a volumetric productivity of $0.364 \mathrm{~g} \mathrm{~L}^{-1} \mathrm{~h}^{-1}$, but there was still $43 \%$ of the glucose left in the fermentation broth. When the YE concentration was increased to $10 \mathrm{~g} \mathrm{~L}^{-1}$ or greater, glucose was depleted and the resultant yields of lactic acid were identical to one another. Nevertheless, the time required to complete the fermentation was significantly different for 10 and $15 \mathrm{~g} \mathrm{~L}^{-1}$ YE. It took $72 \mathrm{~h}$ to consume all of the glucose for $10 \mathrm{~g} \mathrm{~L}^{-1} \mathrm{YE}$ loading, producing $90.9 \mathrm{~g} \mathrm{~L}^{-1}$ lactic acid with a volumetric productivity of $1.265 \mathrm{~g} \mathrm{~L}^{-1} \mathrm{~h}^{-1}$. In case of $15 \mathrm{~g} \mathrm{~L}^{-1} \mathrm{YE}$ loading, fermentation to completion required only $42 \mathrm{~h}$, producing $91.3 \mathrm{~g} \mathrm{~L}^{-1}$ lactic acid with a volumetric productivity as high as $2.168 \mathrm{~g} \mathrm{~L}^{-1} \mathrm{~h}^{-1}$. A further increase in YE concentration to $20 \mathrm{~g} \mathrm{~L}^{-1}$ did not result in higher productivity of lactic acid (Table 3 ). This trend was in good agreement with previous reports. Gao et al. found that when initial YE concentrations were increased from 3 to $15 \mathrm{~g} \mathrm{~L}^{-1}$, productivity of Lactobacillus rhamnosus (NBRC 3863) increased as well, whereas YE concentrations above $15 \mathrm{~g} \mathrm{~L}^{-1}$ did not result in higher productivity. ${ }^{15}$ John et al. also discovered that a further increase of YE supplementation did not show any dramatic change in lactic acid productivity of Lactobacillus delbrueckii (NCIM 2025) and Lactobacillus casei (NCIMB 3254). ${ }^{31}$ However, both of these studies found that the YE concentration, even at a low dosage of $3 \mathrm{~g} \mathrm{~L}^{-1}$ or $0.05 \mathrm{w} / \mathrm{v} \%$, had very little effect on final concentration and yield of lactic acid, which was different from the results in the present study. Dosage of YE at $5 \mathrm{~g} \mathrm{~L}^{-1}$ did not reach the same lactic acid yield as higher YE dosages (Table 3). It seems the LAB strain of Lactobacillus pentosus (ATCC-8041) is more sensitive to nutrient level and requires a higher amount of minimum nutrients to function.

Four levels of CW concentration $\left(10,15,20\right.$, and $\left.30 \mathrm{~g} \mathrm{~L}^{-1}\right)$ and three levels of TW concentration $\left(10,20\right.$, and $\left.30 \mathrm{~g} \mathrm{~L}^{-1}\right)$ were applied to investigate their nutrient effect on lactic acid production. When the fish wastes were used instead of YE for glucose conversion, the efficiency of fermentation was greatly reduced (Fig. 1b and c). With $\mathrm{CW}$ as the nutrient source, the lactic acid yield was only $48.3 \%$ after $96 \mathrm{~h}$ at the highest CW loading of $30 \mathrm{~g} \mathrm{~L}^{-1}$, and the volumetric productivity was $0.460 \mathrm{~g} \mathrm{~L}^{-1} \mathrm{~h}^{-1}$. Half of the glucose was still not consumed. So, the CW was not competitive to YE when it was used in the lactic acid fermentation of pure glucose. On the other hand, although TW contained much less nitrogen content than CW (Table 1), its performance with glucose was superior to CW. At the optimal loading of TW, complete conversion of glucose was observed (Fig. 1c). The lactic acid yields for TW loading of 10,20 and $30 \mathrm{~g} \mathrm{~L}^{-1}$ were $83.1 \%$, 97.3\% and $99.0 \%$, respectively (Table 3 ). The corresponding volumetric productivity was $0.795,0.930$, and $0.949 \mathrm{~g} \mathrm{~L}^{-1} \mathrm{~h}^{-1}$, respectively, which was two times higher than that of $\mathrm{CW}$. Currently, there is not a clear explanation for the superior performance of TW, considering it contained merely $0.46 \mathrm{wt} \%$ nitrogen. A detailed amino acids and B-vitamins analysis might help to give a better understanding. One possible reason is that the TW waste is comprises a bacterial biofloc rather than a simple manure solid, which may make it easier for the LAB to metabolize. Biofloc aquaculture systems create degraded organic waste solids dominated primarily by bacterial biofloc. ${ }^{32}$ As such, they may have an amino acid profile more balanced for LAB metabolism than comparative manure solids from catfish wastes.

\subsection{Effect of different nutrients on SSF of cellulosic materials}

The SSF process was chosen for bioconversion of cellulose and paper sludge into lactic acid in this study. The main advantage of SSF over SHF is that it eliminates the product inhibition of 


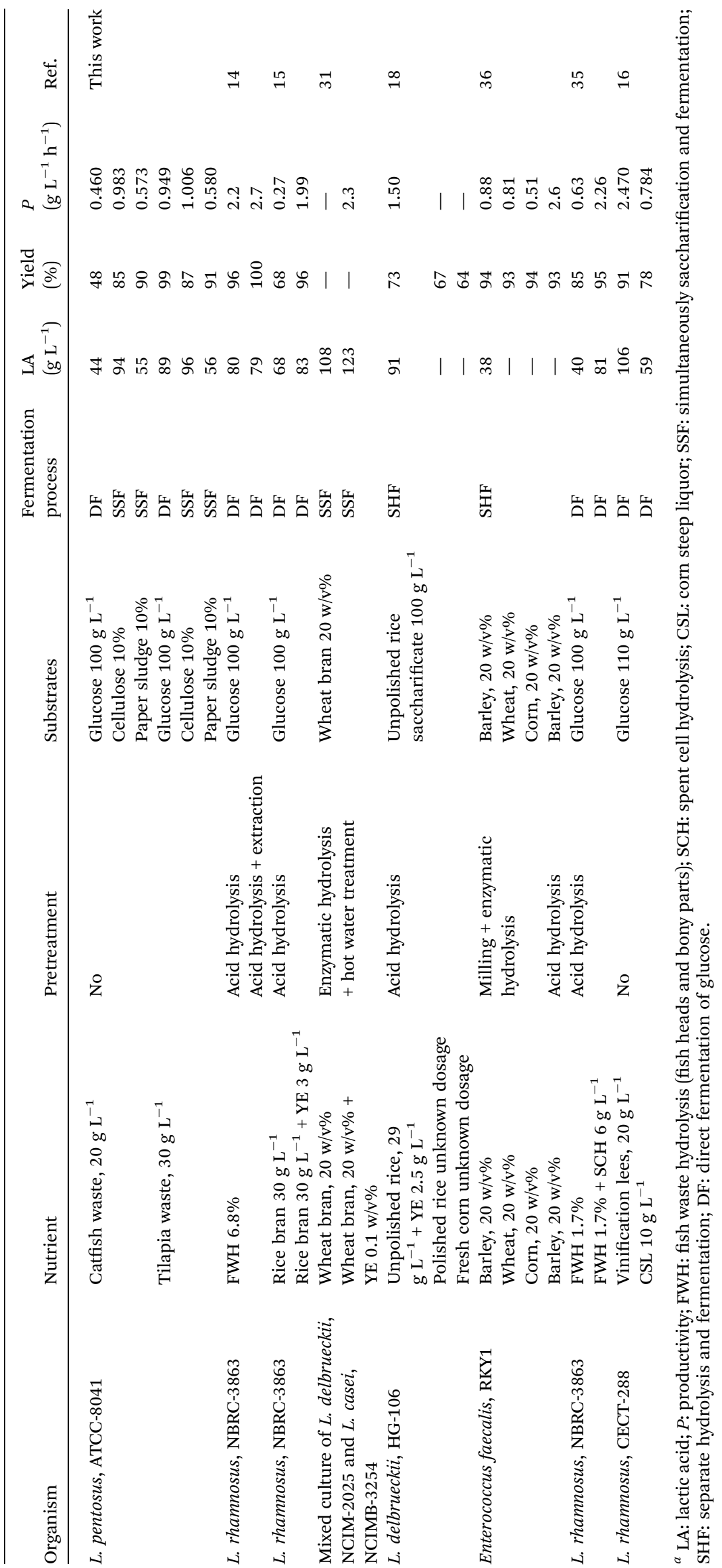


enzymes by sugars and thereby allows for increased sugar digestibility. ${ }^{33,34}$ The sugars released by enzymatic hydrolysis were simultaneously consumed by LAB, so there was no accumulation of sugars during the SSF. The effect of YE concentration on SSF of cellulosic materials was much less dramatic (Fig. 2a and 3a). The lactic acid yield with lower concentration of YE was not substantially different from that with higher YE loadings. Likewise, the volumetric productivity was similar (Table 3). The time required to complete the SSF of cellulose at YE loading of 5, 10, ad $15 \mathrm{~g} \mathrm{~L}^{-1}$ were the same, and the final lactic acid yields were $84 \%, 88 \%$ and $90 \%$, respectively. The SSF of paper sludge with YE showed similar results, where a YE loading of 5, 10 and $15 \mathrm{~g} \mathrm{~L}^{-1}$ resulted in 94\%, 95\% and 96\% lactic acid yield at the same completion time, respectively (Fig. 3a). Due to the nature of the SSF process, sugar hydrolysis and fermentation is carried out simultaneously at a compromising temperature comparing to their individual optimal temperature, and it takes longer time than direct fermentation (DF) of monomeric sugars. The volumetric productivity of SSF was in the range of 0.599 to $1.041 \mathrm{~g} \mathrm{~L}^{-1} \mathrm{~h}^{-1}$ in all cases (Table 3). It seems that the SSF process does not require as much nutrients as direct fermentation and SHF. A very low amount of YE, such as $5 \mathrm{~g} \mathrm{~L}^{-1}$, was adequate to achieve satisfactory lactic acid yield and productivity. Higher concentrations of YE did not bring in noticeable increase in lactic acid yield. We speculate that the reason for the low demand of nutrients is because of the slow release of fermentable sugars in the SSF process. The sugar was gradually hydrolyzed and released by enzyme and was immediately consumed by LAB. There was no sugar accumulation during SSF of cellulose and paper sludge in our study, as only a trace amount of glucose was detected in the fermentation samples (data not shown). The instantaneous sugar concentration during SSF was low, so the need for nutrients of LAB was also reduced compared to the fermentation of high titer sugar solutions.

In contrast to glucose conversion, CW showed promising results in SSF of cellulosic materials. The highest yield from cellulose and paper sludge with CW was $85.4 \%$ and $90.2 \%$ with the volumetric productivity of $0.983 \mathrm{~g} \mathrm{~L}^{-1} \mathrm{~h}^{-1}$ and $0.573 \mathrm{~g} \mathrm{~L}^{-1}$ $\mathrm{h}^{-1}$ respectively, which is comparable to that of YE (Table 3). Similar to the effect of YE on SSF, the CW loading did not show significant impacts on the SSF of cellulose and paper sludge (Fig. $2 \mathrm{~b}$ and $3 \mathrm{~b}$ ). Increase of $\mathrm{CW}$ from $10 \mathrm{~g} \mathrm{~L}^{-1}$ to $30 \mathrm{~g} \mathrm{~L}^{-1}$ resulted in a yield increase of less than $5 \%$. For both feedstocks, the highest yield was obtained at a CW loading of $20 \mathrm{~g} \mathrm{~L}^{-1}$ (Table 3), which was relatively low compared to previous reports. ${ }^{\mathbf{1 4 1 5 , 1 8 , 3 5}}$ The nitrogen content in CW and YE were analyzed to be $3.1 \%$ and $8.9 \%$ respectively. As shown in Table 3, the equivalent nitrogen input from $\mathrm{CW}$ was lower than that from YE, indicating nitrogen utilization efficiency of CW in SSF of both cellulose and paper sludge was higher than that of YE.

Performance of TW in the SSF of cellulose and paper sludge was similar to that of $\mathrm{CW}$. The maximum lactic acid yield for cellulose and paper sludge was $87.4 \%$ and $91.1 \%$, respectively, which were obtained with $30 \mathrm{~g} \mathrm{~L}^{-1}$ TW (Table 3). The corresponding volumetric productivity was 1.006 and $0.580 \mathrm{~g} \mathrm{~L}^{-1} \mathrm{~h}^{-1}$, respectively. Again, the TW loading did not show significant impact on the SSF process (Fig. 2c and 3c). Increase of TW from $10 \mathrm{~g} \mathrm{~L}^{-1}$ to $30 \mathrm{~g} \mathrm{~L}^{-1}$ resulted in less than $10 \%$ yield increase.

\subsection{Comparison with other low-cost nutrients}

To evaluate the performance of fish waste in lactic acid production, some low-cost nutrients were compared in Table 4. It was found that if YE were replaced by other inexpensive nutrients, there was a decrease in lactic acid production or an increase in fermentation period. ${ }^{\mathbf{1 4 , 1 5 , 1 8 , 3 6}}$ To raise fermentation efficiency, the alternative nutrients had to be used in large quantities. Gao et al. used $68 \mathrm{~g} \mathrm{~L}^{-1}$ of fish processing waste to obtain results comparable to $15 \mathrm{~g} \mathrm{~L}^{-1} \mathrm{YE}^{\mathbf{1 4}}$ The same group also found that $30 \mathrm{~g} \mathrm{~L}^{-1}$ of rice bran could result in productivity comparable to about $8 \mathrm{~g} \mathrm{~L}^{-1} \mathrm{YE.}^{15}$ The high dosage of the nutrient sources would bring in problem of high impurities, however, and a greater amount of supplemented nutrients increases downstream separation costs. Some researchers used a strategy of combining nutrient sources to increase the efficiency and lower the nutrient dosage. Lu et al. achieved $1.5 \mathrm{~g} \mathrm{~L}^{-1}$ $\mathrm{h}^{-1}$ lactic acid productivity by combining wheat bran powder of $29.1 \mathrm{~g} \mathrm{~L}^{-1}$ and $2.5 \mathrm{~g} \mathrm{~L}^{-1} \mathrm{YE.}^{18}$ Gao et al. successfully reduced the fish processing waste loading from $68 \mathrm{~g} \mathrm{~L}^{-1}$ to $17 \mathrm{~g} \mathrm{~L}^{-1}$ by mixing with $6 \mathrm{~g} \mathrm{~L}^{-1}$ spent cells. ${ }^{35}$ In the present study, $20 \mathrm{~g} \mathrm{~L}^{-1}$ CW showed satisfactory lactic acid production in SSF with no YE supplement.

Another important advantage of using fish waste as nutrients in fermentation is that it does not require any pretreatment steps. Other low-cost nutrients such as fish processing waste, rice bran, wheat bran, barley, and corn, etc. were in need of a more complicated thermal-chemical and/or enzymatic hydrolysis pretreatment step..$^{\mathbf{1 4 , 1 5 , 1 8 , 3 5 , 3 6}}$ The untreated materials could only lead to very low lactic acid productivity and yield. The pretreatment step is neither economically favorable nor environment-friendly due to the use of inputs of chemicals, enzymes, or high thermal energy. The use of fish waste as presented here could bypass pretreatment, thereby making a more attractive nutrient source for lactic acid production at large scale.

\section{Conclusions}

The use of fish manure wastes as nutrient source for lactic acid fermentation from glucose was insufficient compared to yeast extract. However, it is feasible to use fish wastes as a nutrient source for lactic acid production from cellulosic materials by SSF process. Both tilapia and catfish wastes from aquaculture were found to be adequate nutrient sources for LA production from cellulosic materials, at an optimum loading of $20 \mathrm{~g} \mathrm{~L}^{-1}$. This sort of fermentation strategy could not only reduce the cost for lactic acid production, but also help to prevent aquatic pollution by consuming a waste product that is otherwise disposed of in the environment. The relatively low loading requirement of fish waste could ease the burden of downstream separation. Elimination of a pretreatment step makes the utilization of fish waste more economic and environmentally friendly than other potential low-cost nutrient sources. 


\section{Conflicts of interest}

There are no conflicts to declare.

\section{Acknowledgements}

The authors gratefully acknowledge the contributions of Mollie Smith, Mary Catherine Rubisch, and Erin Landers of Auburn University for the care of fish and the collection of waste. Care of fish and access to the aquaculture system was provided by $\mathrm{Dr}$ Eric Peatman and the Aquatic Genetics and Genomics Laboratory at Auburn University. Access to fish aquaculture facilities was provided by the E. W. Shell Fisheries Center and the Auburn University School of Fisheries, Aquaculture, and Aquatic Sciences. We also would like to thank Novozymes, North America for providing C-Tec 2 enzyme, and Boise Paper Company, Jackson, AL for providing the paper sludge. This research was supported in part by Agriculture and Food Research Initiative Competitive Grant from the USDA National Institute of Food and Agriculture [Grant number 2016-7000725758], by the United Soy Board [Grant number 1630-51252111], and by the Alabama Agricultural Experiment Station.

\section{References}

$1 \mathrm{H}$. Tsuji, Bio-based plastics: materials and applications, 2013, pp. 171-239.

2 E. Castro-Aguirre, F. Iñiguez-Franco, H. Samsudin, X. Fang and R. Auras, Adv. Drug Delivery Rev., 2016, 107, 333-366.

3 K. J. Jem, J. F. van der Pol and S. de Vos, in Plastics from bacteria, Springer, 2010, pp. 323-346.

4 Y. Wang, Y. Tashiro and K. Sonomoto, J. Biosci. Bioeng., 2015, 119, 10-18.

5 P. Laopaiboon, A. Thani, V. Leelavatcharamas and L. Laopaiboon, Bioresour. Technol., 2010, 101, 1036-1043.

6 A. Dumbrepatil, M. Adsul, S. Chaudhari, J. Khire and D. Gokhale, Appl. Environ. Microbiol., 2008, 74, 333-335.

7 F. Cui, Y. Li and C. Wan, Bioresour. Technol., 2011, 102, 18311836.

8 S. Shi, L. Kang and Y. Lee, Appl. Biochem. Biotechnol., 2015, 175, 2741-2754.

9 T. L. Miller and B. W. Churchill, Substrates for large-scale fermentations, in Manual of Industrial Microbiology and Biotechnology, ed. A. L. Demain and N. A. Solomon, American Society for Microbiology, Washington, DC, 1986.

10 J. Hugenholtz and M. Kleerebezem, Curr. Opin. Biotechnol., 1999, 10, 492-497.

11 T. Payot, Z. Chemaly and M. Fick, Enzyme Microb. Technol., 1999, 24, 191-199.

12 K. Lee, Bioresour. Technol., 2005, 96, 1505-1510.

13 A. Aeschlimann and U. Von Stockar, Appl. Microbiol. Biotechnol., 1990, 32, 398-402.
14 M.-T. Gao, M. Hirata, E. Toorisaka and T. Hano, Bioresour. Technol., 2006, 97, 2414-2420.

15 M.-T. Gao, M. Kaneko, M. Hirata, E. Toorisaka and T. Hano, Bioresour. Technol., 2008, 99, 3659-3664.

16 G. Bustos, A. B. Moldes, J. M. Cruz and J. M. Domínguez, J. Agric. Food Chem., 2004, 52, 801-808.

17 C. M. Hsieh, F.-C. Yang and E. L. Iannotti, Process Biochem., 1999, 34, 173-179.

18 Z. Lu, M. Lu, F. He and L. Yu, Bioresour. Technol., 2009, 100, 2026-2031.

19 X. Zhou, FAO Aquaculture Newsletter, 2017, 6.

20 National Marine Fisheries Service, Fisheries of the United States, 2016, U.S. Department of Commerce, 2017, NOAA Current Fishery Statistics No. 2016, Available at: https:// www.fisheries.noaa.gov/resource/document/fisheries-unitedstates-2016-report.

21 A. Zajdband, Seafood Watch, 2012.

22 Catfish Production, National Agricultural Statistics Service (NASS), Agricultural Statistics Board, United States Department of Agriculture (USDA), February 2, 2018, ISSN: 1948-271X, Available at: http://usda.mannlib.cornell.edu/ usda/nass/CatfProd//2010s/2018/CatfProd-02-02-2018.pdf.

23 C. E. Boyd, J. Queiroz, J. Lee, M. Rowan, G. N. Whitis and A. Gross, J. World Aquacult. Soc., 2000, 31, 511-544.

24 D. Miller and K. Semmens, Waste management in aquaculture, West Virginia University Extension Service Publication No. AQ02-1, USA, 2002, p. 8.

25 S. Benjakul and M. T. Morrissey, J. Agric. Food Chem., 1997, 45, 3423-3430.

26 S. Shi, J. Li and D. M. Blersch, Appl. Microbiol. Biotechnol., 2018, 102, 4765-4772.

27 R. Crab, T. Defoirdt, P. Bossier and W. Verstraete, Aquaculture, 2012, 356, 351-356.

28 N. V. Hue and C. Evans, Procedures used by the Auburn University soil testing laboratory, 1979.

29 A. Sluiter, B. Hames, R. Ruiz, C. Scarlata, J. Sluiter, D. Templeton and D. Crocker, Laboratory analytical procedure, 2008, 1617, pp. 1-16.

30 A. Nancib, N. Nancib, D. Meziane-Cherif, A. Boubendir, M. Fick and J. Boudrant, Bioresour. Technol., 2005, 96, 63-67.

31 R. P. John, K. M. Nampoothiri and A. Pandey, Biotechnol. Lett., 2006, 28, 1823-1826.

32 Y. Avnimelech, Aquaculture, 2007, 264, 140-147.

33 S. Marques, J. A. Santos, F. M. Gírio and J. C. Roseiro, Biochem. Eng. J., 2008, 41, 210-216.

34 M. Takagi, Chemicals and Microbial protein, 1977.

35 M.-T. Gao, M. Hirata, E. Toorisaka and T. Hano, Biochem. Eng. J., 2007, 36, 276-280.

36 H. Oh, Y.-J. Wee, J.-S. Yun, S. H. Han, S. Jung and H.-W. Ryu, Bioresour. Technol., 2005, 96, 1492-1498. 